Oksana Manchenko and Valeriy Nizhnik

\title{
ROLE OF THE STRUCTURE AN D COMPOSITION OF MACROMOLECULE CHAIN IN CHEMICAL PLASTICIZATION OF POLYMERS
}

\author{
Kyiv National University named after Taras Shevchenko \\ 60, Volodymyrska str., 03110 Kyiv, Ukraine
}

Received: J une 03, 2013/Revised: J une 26, 2013 / Accepted: December 27, 2013

(C) Manchenko O., Nizhnik V., 2014

\begin{abstract}
The correlation between the parameters of chemically plasticized polar polymers (glass transition temperature, solubility parameter, cohesive energy, polarizability, modulus of elasticity in shear) with polarity and van der Waals volume of macromolecule link was investigated. It was shown that the chemical plasticization of PVAc and PVME by the alkylated polar groups replacement in weakly polar methyl group is not associated with the parameters of isolated macromolecule and is mainly determined by the intermolecular interaction. The chemical plasticization for the polyacid and polybase occurs via alkylation carboxyl and hydroxyl groups accordingly. The methyl ether of poly(acrylic acid) chemical plasticization is observed at increase of an alkyl radical size.
\end{abstract}

Keywords: chemical plasticization, polarizability, van der Waals volume, glass transition temperature.

\section{Introduction}

At the chemical (internal) polymer plasticization the reduction of potential barrier of internal rotation of units in macrochain and weakening of the attraction between macromolecules are achieved by changing the chemical structure of the polymer [1].

The potential barrier of internal rotation depends on the energy of intramolecular and intermolecular interactions and is determined by the chemical nature of the functional groups comprising the units, as well as by the units structure [2].

The presence of polar functional groups leads to an increase in the intensity of both types of interactions. These polar groups can be located in the chain next to each other and then they create a significant interaction of short-range order. This increases the rigidity of the chain macromolecule. Addition of nonpolar fragments into the link between polar groups weakens this interaction.
The aim of this paper is establishment of the main factors that cause the effect of the chemical plasticization in amorphous polymers by changing the composition and structure of the macromolecules links.

\section{Results and Discussion}

We compared the glass transition temperature $\left(T_{g}\right)$, cohesive energy $\left(E_{c o h}\right)$, modulus of elasticity in shear $\left(G_{a}\right)$ and other parameters of such polymers: polyvinyl acetate (PVAc), polyvinyl methyl ether (PVME), and polypropylene (PP). Links of these polymers differ by positions of methyl group towards the main chain of the macromolecule. This group is attached to the main carbochain through polar group - $\mathrm{COO}-$ with dipole moment $\mu_{g r}=0.7 \mathrm{D}$ in PVAc, through less polar group $\mathrm{O}-\left(\mu_{g r}=0.46 \mathrm{D}\right)$ in PVME and directly linked to the chain in PP. For carbochain polymers with chains which contain side groups one possible method is to reduce the plasticizing chemical polarity units of macromolecules by changing the polarity of the side groups. For the polymers mentioned above replacement of polar side groups in links by weakly polar $-\mathrm{CH}_{3}$ group with a dipole moment $\mu_{g r}=$ $=0.37 \mathrm{D}[3]$ reduces the dipole-dipole interaction between different parts of the macromolecules and changes the parameters of macromolecules and polymer in accordance with the chemical plasticization. Chemical formula units and parameters mentioned polymers with different chemical composition units are listed in Table 1.

The values of $T_{g}$ and of the dipole moments of the functional groups of links $\mu$ were taken from [4, 5]. Van der Waals volume of the polymer limited by electron clouds of molecules and attributed to the monomer unit $\left(V_{v w}\right)$ was calculated according to [4] by the formula:

$$
\frac{V}{V_{V W}}=1.55
$$

where $V$ - molar volume of the polymer in the glassy state, attributed to the monomer unit. 
Parameters of polymers

\begin{tabular}{|c|c|c|c|}
\hline Parameters & 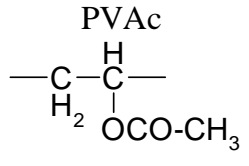 & $\begin{array}{l}\mathrm{PVME} \\
-\mathrm{H} \\
-\mathrm{C}-\mathrm{C}- \\
\mathrm{H}_{2} \underset{\mathrm{O}}{\mathrm{O}-\mathrm{CH}_{3}}\end{array}$ & $\begin{array}{c}\mathrm{PP} \\
-\mathrm{H} \\
-\mathrm{C}-\mathrm{C} \\
\mathrm{H}_{2} \stackrel{\mathrm{I}}{\mathrm{C}}-\mathrm{H}_{3}\end{array}$ \\
\hline$T_{g}, \mathrm{~K}$ & 301 & 260 & 253 \\
\hline$\rho 10^{-3}, \mathrm{~kg} / \mathrm{m}^{3}$ & 1.19 & 1.12 & 0.85 \\
\hline$V_{v w} 10^{6}, \mathrm{~m}^{3} / \mathrm{mol}$ & 46.6 & 36.9 & 31.1 \\
\hline$U_{i r}, \mathrm{~kJ} / \mathrm{mol}$ & 4.5 & 4.5 & 11.5 \\
\hline$m$ & 6.9 & 6.2 & 8.6 \\
\hline$\sigma$ & 2.2 & 2.1 & 2.4 \\
\hline$\mu_{g r}, \mathrm{D}$ & 0.7 & 0.45 & 0.37 \\
\hline$\mu_{a,}, \mathrm{D}$ & 0.65 & 0.42 & - \\
\hline$\varepsilon$ & 3.2 & 3.0 & 2.15 \\
\hline$\delta 10^{-3}, \mathrm{~J}^{1 / 2} \mathrm{~m}^{3 / 2}$ & 10.6 & 9.9 & 7.1 \\
\hline$E_{\text {coh }}, \mathrm{kJ} / \mathrm{mol}$ & 27.6 & 14.4 & 11.8 \\
\hline$P 10^{3}, \mathrm{~m}^{3} / \mathrm{kmol}$ & 28.9 & 19.11 & 13.91 \\
\hline$G_{a} \cdot 10^{-9}, \mathrm{~N} / \mathrm{m}^{2}$ & 1.0 & 0.9 & 0.89 \\
\hline
\end{tabular}

$$
V=\frac{M}{\rho}
$$

where $M-$ molecular weight of monomer link; $\rho-$ polymer density.

The energies of internal rotation $\left(U_{i r}\right)$ of groups around the valence-bond $\mathrm{C}-\mathrm{C}$ for $\mathrm{PP}$ and $\mathrm{C}-\mathrm{O}$ for PVAc and $\mathrm{PVME}$, the number of monomer units in the segment $(m)$, and chain stiffness factor $(\sigma)$ are taken from $[6,7]$.

$$
\sigma=\frac{\left\langle h_{\theta}\right\rangle^{1 / 2}}{\left\langle h_{f j c}\right\rangle^{1 / 2}}
$$

where $\left\langle h_{\theta}\right\rangle^{1 / 2}$ - unperturbed coil size in $\theta$-solvent; $\left\langle h_{f j c}\right\rangle^{1 / 2}-$ size of freely-jointed chain.

Group contributions to molar polarization of polymer $\left(P_{V}\right)$ were taken from [4].

From the ratio $P_{V}=E^{1 / 2} M$ the relative dielectric constant of the polymer $(\varepsilon)$ and from the ratio $\delta \approx 3.3 \varepsilon$ solubility parameter $(\delta)$ were calculated.

Solubility parameter is related to the energy density of cohesion $e_{c o h}=\left(\frac{E_{c o h}}{V}\right)^{1 / 2}$ by the ratio $\delta=e_{c o h}^{1 / 2}$.

The average dipole moment of the polymer unit ( $\mu$ a) was calculated by the Debye equation

$$
20.6 \mu_{a}=P-R_{L L}
$$

where $P$ - molar polarization of polymer insulator, $R_{L L}-$ molar refraction according to Lorentz and Lorenz. $P$ and $R_{L L}$ were calculated by group contributions as in [4].

Molar cohesion energy of link of polymer $\left(E_{c o h}\right)$ was calculated according to [8] by structural groups contributions to this energy:

$$
\left(E_{c o h} V\right)^{1 / 2}=F
$$

where $F$ - molar attraction constant.

Shear modulus of the polymer in the amorphous state or its stiffness $\left(G_{a}\right)$ were determined from empirical Van Krevelen and Hoftyzer correlation:

$$
G_{a} \approx \frac{3}{1+\frac{600}{T_{C}}} 10^{9} \mathrm{~N} / \mathrm{m}^{2}
$$

Analysis of polymers parameters listed in Table 1 shows that the decrease of $T_{g}, \delta, E_{c o h}, P, \rho$ and $G_{a}$ at the replacement of alkiled polar groups by weekly polar methyl group in PVAc and PVME cannot be associated with the characteristics of isolated macromolecule $-U_{v o}$, $m$ and $\sigma$. Internal rotation in the gauche-conformation of polypropylene is hampered more than in the above polar polymers due to larger value of van der Waals radius of the $\mathrm{CH}_{3}$ group $(\sim 2.1 \AA)$ compared to the van der Waals radius of oxygen $(\sim 1.5 \AA)$. That is, in isolated state macromolecules chains of polar polymers are more flexible compared to the non-polar polymer chains, which is not observed in polymers in bulk. In particular, Kuhn segment for isolated PVAc macromolecule consists of 6.9 monomer units and has the size of $1.74 \mathrm{~nm}$, and for the $\mathrm{PE}$, this segment has 8.6 monomer units and the size of $2.17 \mathrm{~nm}$ [9].

The general conclusion from the analysis of data in Table 1 is that the chemical plasticization investigated in a number of polymers is mainly determined by intermolecular interactions rather than intramolecular. Reduction of $T_{g}, \delta, E_{c o h}, P, \rho$ and $G_{a}$ in series of PVAcPVME-PP according to the data in Table 1 is connected 
Role of the Structure and Composition of M acromolecule Chain in Chemical Plasticization of... 325

with the effect of internal rotation of the intermolecular interaction. Electrical forces caused by polarizability $(\varepsilon)$, group- and unit- dipole moment cause a significant decrease in chain flexibility of the studied polar polymers as well as growth of cohesive, electrical, and mechanical parameters and density of the polymer. Due to these forces, which have dipole-dipole nature, polar functional groups and polar links form stable interchain bonds between interchain multipolar macromolecules, which significantly inhibit internal rotation of links. Replacing the strong electrical forces of attraction by the weak van der Waals forces (in PP) significantly reduces inhibition of internal rotation of links belonging to different chains. This causes reduction in $T_{g}$ polymer, reducing its density, solubility parameter, cohesive energy, and elastic modulus in shear.

Polar substituents form particularly stable interchain bonds, which prevent internal rotation of links, when their nature is conditioned by hydrogen bonds. These polymers are, for example, polyacids and polybases. For these polymers chemical plasticization is possible via alkylation of acid carboxyl groups and alkylation of polybases hydroxyl groups. Such alkylation reduces activity of the lateral groups. Parameters of polyacrylic acid - PAA, polyvinyl alcohol - PVA, and esterified compounds - polymethylacrylates (PMA) and polyvinylmethyl ether (PVME) are given in Table 2.

The glass transition temperature data are taken from the works $[4,5], G_{a}$ or rigidity, $\delta$, and $V_{v w}$ values for the amorphous state polymers were calculated according to [4]. The polymers density was determined according to [10].

As shown in Table 2, at the formation of polyacid ester and polyalcohol ether, respectively, the glass transition temperature of the polymer, its density, solubility parameter and $G_{a}$ decrease due to increasing of the the polymer link van der Waals volume. That is, esterification via substitution of hydrogen interchain bonds by the van der Waals ones reduces spatial impediments to macromolecule segments shifting and thereby facilitates the conformational conversion of macromolecules with increasing temperature.

Methyl side group causes an increase in the van der Waals volume of the polymer link, therefore reducing its density, solubility parameter, and modulus of elasticity in shear. That is, by changing the nature of the attractive forces between macromolecules this group serves as a diluent in the bulk polymer. Therefore, it can be assumed that increasing the size of alkyl radical increases the effect of dilution.

Table 2

Parameters of polyacrylic acid, polyvinyl alcohol and their methyl ester and ether

\begin{tabular}{|c|c|c|c|c|}
\hline Parameters & 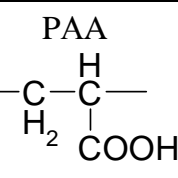 & $\begin{array}{c}\mathrm{PMA} \\
\mathrm{C}-\stackrel{\mathrm{H}}{\mathrm{C}}-\stackrel{\mathrm{l}}{\mathrm{COOCH}} \mathrm{CH}_{3}\end{array}$ & $\begin{array}{c}\mathrm{PVA} \\
-\mathrm{C}-\stackrel{\mathrm{H}}{\mathrm{C}}- \\
\mathrm{H}_{2} \stackrel{\mathrm{O}}{\mathrm{O}}-\end{array}$ & $\begin{array}{l}\mathrm{PVME} \\
\stackrel{\mathrm{H}}{\mathrm{C}}-\stackrel{\mathrm{C}}{\mathrm{C}}- \\
\mathrm{H}_{2} \stackrel{\mathrm{O}}{\mathrm{O}-\mathrm{CH}_{3}}\end{array}$ \\
\hline$T_{g}, \mathrm{~K}$ & 379.0 & 281 & 343 & 260 \\
\hline$\rho \cdot 10^{-3}, \mathrm{~kg} / \mathrm{m}^{3}$ & 1.7 & 1.22 & 1.26 & 1.12 \\
\hline$V_{v w} \cdot 10^{6}, \mathrm{~m}^{3} / \mathrm{mol}$ & 27.39 & 45.5 & 22.6 & 36.9 \\
\hline$\delta \cdot 10^{-3}, \mathrm{~J}^{1 / 2} \mathrm{~m}^{3 / 2}$ & 10.1 & 9.7 & 11.4 & 9.9 \\
\hline$G_{a} \cdot 10^{-9}, \mathrm{~N} / \mathrm{m}^{2}$ & 1.16 & 0.97 & 1.09 & 0.9 \\
\hline
\end{tabular}

Table 3

Parameters of polyacrylic acid esters

\begin{tabular}{|c|c|c|c|c|}
\hline Parameters & $\begin{array}{c}\text { PMAA } \\
-\stackrel{\mathrm{H}}{\mathrm{C}}-\stackrel{\mathrm{C}}{\mathrm{H}}-{ }_{\mathrm{COOCH}}\end{array}$ & $\begin{array}{c}\stackrel{\text { PEAA }}{\stackrel{\mathrm{H}}{\mathrm{C}}-} \\
-\underset{\mathrm{H}}{\mathrm{H}}-\stackrel{\mathrm{I}}{\mathrm{COOC}_{2} \mathrm{H}_{5}}\end{array}$ & $\begin{array}{c}\text { PPAA } \\
-\stackrel{H}{\mathrm{C}}-\stackrel{\mathrm{C}}{\mathrm{I}}- \\
\mathrm{H}_{2} \mathrm{COOC}_{3} \mathrm{H}_{7}\end{array}$ & 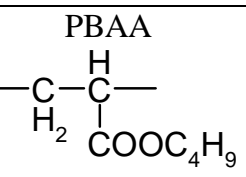 \\
\hline$M$ & 86 & 100 & 114 & 128 \\
\hline$T_{g}, \mathrm{~K}$ & 281 & 251 & 229 & 221 \\
\hline$\rho \cdot 10^{-3}, \mathrm{~kg} / \mathrm{m}^{3}$ & 1.22 & 1.12 & 1.08 & 1.0 \\
\hline$V_{s p} 10^{3}, \mathrm{~m}^{3} / \mathrm{kg}$ & 0.82 & 0.89 & 0.92 & 1.0 \\
\hline$V_{v w} \cdot 10^{6}, \mathrm{~m}^{3} / \mathrm{mol}$ & 45.5 & 57.6 & 68.1 & 82.6 \\
\hline$\delta \cdot 10^{-3}, \mathrm{~J}^{1 / 2} \mathrm{~m}^{3 / 2}$ & 9.7 & 9.2 & 9.05 & 8.8 \\
\hline$G_{a} 10^{-9}, \mathrm{~N} / \mathrm{m}^{2}$ & 0.97 & 0.88 & 0.83 & 0.81 \\
\hline
\end{tabular}


Conformational conversions of polymer chain, which includes links with large in size and weight side groups require considerable energy and cause significant inhibition of internal rotation of links [11]. However, when the dipole side group is not connected directly to the main carbochain, as in polyacrylates, the orientation of dipole moments occurs regardless of changes in the macromolecule conformation, which is caused, for example, by temperature increase. In such case the presence of large-sized side groups should weaken the attraction between macromolecules through steric obstacles and cause chemical plasticizing effect. Table 3 shows the parameters of several esters of polyacrylic acid: methyl (PMAA), ethyl (PEAA), propyl (PPAA), and butyl (PBAA).

Increase of the alkyl radical size, as seen from Table 3, leads to further reduction of the glass transition temperature, density of polymer, solubility parameter, and modulus of elasticity in shear. That is, liquefying ability of alkyl radical increases with increase of its size. Size of alkyl radical affects the specific volume of the polymer, the latter increases while passing from methyl to butyl radical. This shows that the share of the "free" volume increases with increasing size of alkyl radical, internal rotation of links of neighboring macromolecules is facilitated, leading to decrease in the glass transition temperature.

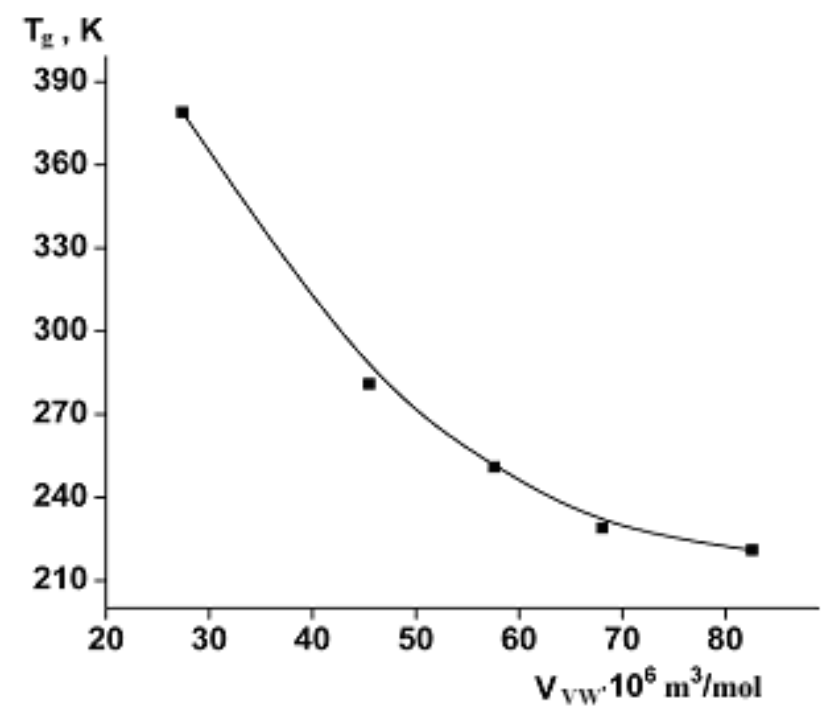

Fig. 1. Dependence of $T_{g}$ on van der Waals volume $V_{v w}$ in monomer link at chemical plasticization of polyacrylic acid

From the data of Tables 2 and 3, we can set the dependence of $T_{g}$ on the van der Waals polyethers and polyesters link size. This dependence is shown in Fig. 1. The figure shows that methylation of polyacrylic acid dramatically reduces the glass transition temperature of the polymer. As noted above, this is due to replacement of strong electrical forces of attraction by weak van der Waals forces. Sequential replacement of methyl groups by the larger ethyl, butyl and propyl ones leads to further reduction in $T_{g}$, although the $T_{g}$ decrease rate slows down.

This is because the nature of the attractive forces between macromolecules changes insignificantly with increasing size of the side group, but the density of packing of the side groups in the bulk polymer decreases under the influence of steric factors.

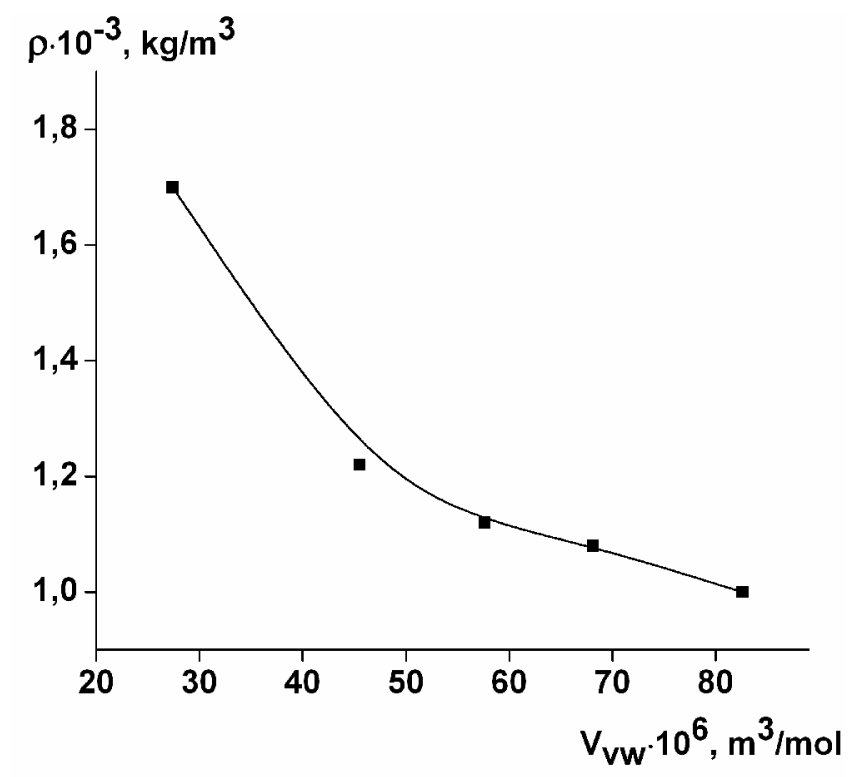

Fig. 2. Dependence of density $\rho$ on van der Waals volume $V_{v w}$ in monomer link with chemical plasticization of polyacrylic acid

The polymer density decreases, thereby increasing its "free" volume (Fig. 2). For different polymers share of free volume at $T_{g}$ is constant [12]. Since free volume increases with the size of the alkyl group of polyacrylic acid ester, reaching of critical free volume, which corresponds to $T_{g}$, for higher homologues will occur at lower temperatures.

\section{Conclusions}

It has been shown that chemical plasticization can occur through reducing the polarity of the side groups of macromolecules links, and at a constant number of functional groups of one polarity through reducing the density of packing of the side groups of macromolecules links and macromolecules in the bulk polymer. Both factors lead to weakening of attraction between macromolecules, which leads to decrease in glass transition temperature, density, solubility parameter, and modulus of elasticity in shear of the polymer. 


\section{References}

[1] Nizhnik V., Paskal L., Linets L. and Moskalenko T.: Dopovidi Nats. Acad. Nauk Ukrainy, 2002, 10, 147.

[2] Tager A.: Physico-Khimiya Polymerov. Khimiya, Moskwa 1978.

[3] Exner O.: Dipole Moments in Organic Chemistry. Georg Thieme Publ., Stuttgart 1975.

[4] van Krevelen D. (Ed.): Properties of Polymers: Their Correlation with Chemical Structure; their Numerical Estimation and Prediction from Additive Group Contributions. Elsevier, NY 2009.

[5] Lipatov Yu., Nesterov A., Grishchenko T. and Veselovsky R.: Spravochnik po Khimii Poolymerov. Naukova dumka, Kyiv 1971.

[6] Kuleznev V. and Shershnev V.: Khimiya i Physika Polymerov. Vyshaya schkola. Moskwa 1988.

[7] Privalko V.: Molekulyarnoe Stroenie i Svoistva POlymerov. Khimiya. Leningrad 1986.

[8] Small P.: J. Appl. Chem., 1953, 3, 71.

[9] Bresler S. and Erusalimsky B.: Physikai Khimiya Macromolecul. Nauka, Moskwa-Leningrad 1965.

[10] Manchenko O., Nizhnik V. and Linets L.: Khimichna Plastyfikaciya Polyalkylmetacrylativ - Magisterium, 2013, 51, 40.

[11] Birshtein T. and Ptitsyn O.: Konformatsii Mactomolecul. Nauka, Moskwa 1964.
[12] Nizhnik V. and Nizhnik T.: Physichna Khimiya Polymeriv. Fitosociocentr, Kyiv 2009.

\section{РОЛЬ БУДОВИ І СКЛАДУ ЛАНКИ У МАКРОМОЛЕКУЛІ В ХІМІЧНІЙ ПЛАСТИФІКАЦІЇ ПОЛІМЕРІВ}

Анотація. Встановлена корелячія між характеристиками пластифікованих полярних аморфних полімерів (температурою склування, параметром розчинності, енергією когезіі, поляризусмістю, модулем пружності при зсуві) 3 полярністю та Ван-дер-Ваальсовим об' смом ланки макромолекули. Показано, щзо хімічна пластифікація полівінілацетету та полівінілметилового естеру заміною алкільованих полярних груп на слабо полярну метильну не пов'язана з параметрами ізольованої макромолекули, а визначається головним чином міжмолекулярною взаємодією. Для полікислоти та поліоснови хімічна пластифікачія відбувається через алкілування відповідно карбоксильних та гідроксильних груп. Хімічна пластифікація метилового естеру поліакрилової кислоти спостерігається при збільшенні розміру алкільного радикалу.

Ключові слова: хімічна пластифікаиія, поляризуємість, Ван-дер-Ваальсовий об'єм, температура склування. 